\title{
Digitalization of Ethno Constructivism Based Module for Elementary School Students
}

\author{
Asrial $^{1^{*}}$, Syahrial, Dwi Agus Kurniawan, Qalbi Shanaz Anandari \\ Universitas Jambi, Jl. Raya Jambi, KM 15, Mendalo Indah, Jambi, 36361 \\ lasrial@unja.ac.id* \\ *corresponding author
}

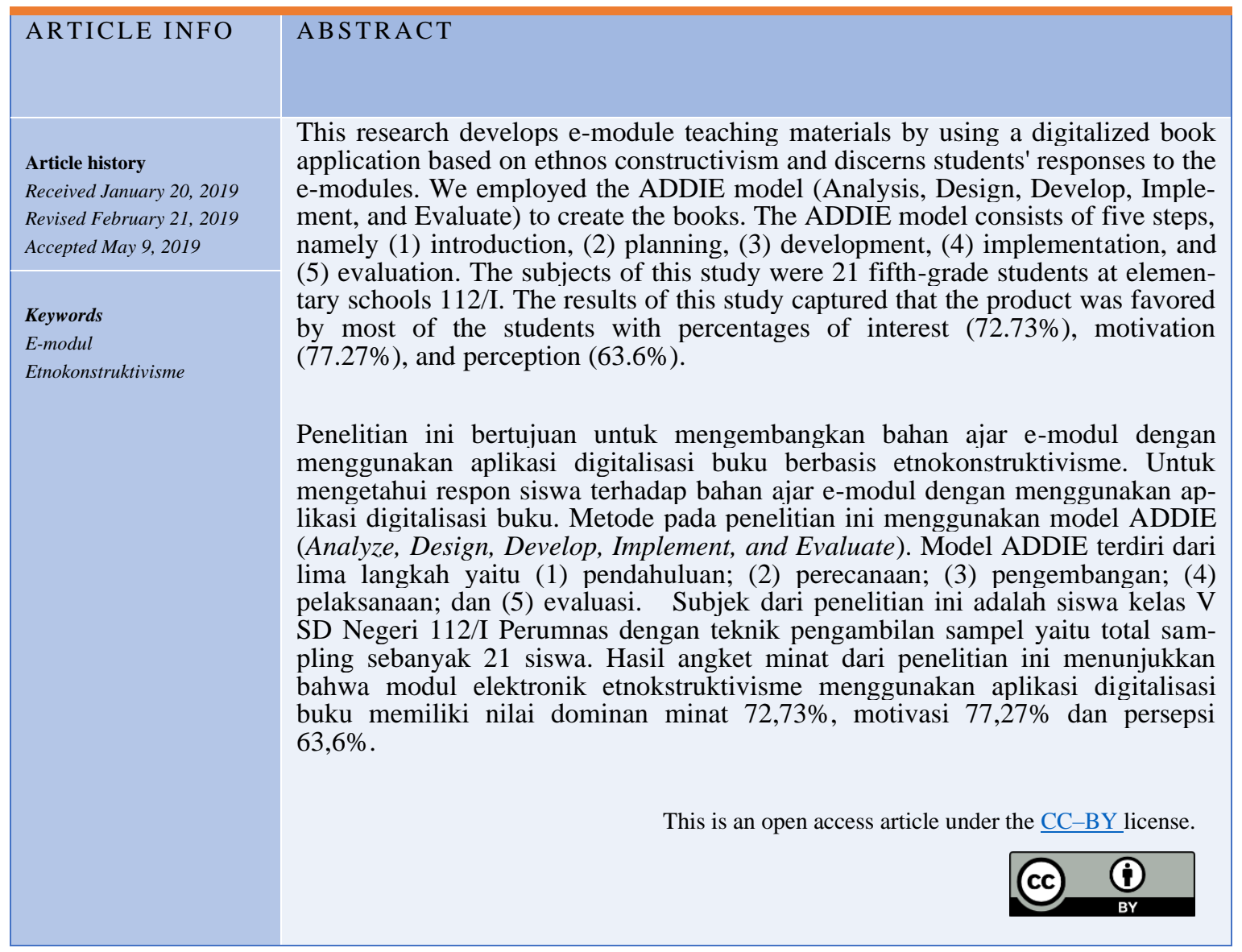

\section{Introduction}

Education is a process of exploring knowledge, skills, and habits in life. Education is basically a conscious effort to develop the potential of human resources, especially students, which is done by guiding and facilitating their learning activities (Astalini et al., 2018). Education is not only a medium to pass down culture to the next generation but is also expected to be able to change and develop the nation's lifestyle for the better. Education is also a long-term investment that we must prepare. So that we have a better life in the future (Nafiati, 2017)

Nowadays, globalization provides many influences on education in Indonesia to better and developing. The influence of globalization is felt using ICT in teaching and learning. The concepts of globalization, nation-states, and education are closely interrelated. As already mentioned, globalization has brought a total rethinking of political and social structures, economic relations and cultural values (Parjanadze, 2009) As educators, and teachers have a significant role in overcoming this, teachers must be able to filter foreign cultures into student thought patterns.

The teacher who makes great activation of his roles in classroom management and enriches learners' knowledge (Ibrahim, 2016). The teacher must also be able to process the development of ICT in a positive direction so 
that students do not forget the original culture of Indonesia as a national identity. Teachers in a learning process are required to be able to create an effective learning environment and be able to manage the class, so that prospective teachers get optimal learning outcomes (Asrial et al. 2019).

ICT applied in education in Indonesia aims to improve the quality of Indonesian education. ICTs make an acquisition of knowledge more accessible, and concepts in the field of learning also determine when involving students in the application of ICTs (Fu, 2013). The teacher must also be able to teach students how to operate ICT. According to (D. Darmaji et al. 2018), "Quality teachers do have not only knowledge but also have skills." Technology-based education is one alternative that can be used by teachers in the learning process. Content that can be enjoyed more easily, and whatever is available can use learning resources effectively or can activate the content themselves at home or school (Kaewkiriya, 2013). E-learning can be used as a learning medium so that it can facilitate teachers in delivering learning material in class. Computers, audio-visual learning media, are considered to have the advantages of learning rather than using print media visual (Darmaji et al., 2019).

Learning media is an important part of learning (Susanti, 2015). Besides being an essential part of learning, instructional media is also an inseparable part of the teaching and learning process. The purpose of utilization and learning resources in class is to assist the teacher with the presentation and transmission of educational content and the achievement of educational objectives while aiding the students in acquiring knowledge and profiling different abilities and values (Bušljeta, 2013). Examples of learning media commonly used are print and non-print media. The use of print media, such as books, is widely used in schools to support the learning process. Compared to print media, the use of non-print media is still relatively small due to the lack of non-print media development.

Learning can succeed well if it is implemented using appropriate media (Ratminingsih, 2018). Choosing the right media is believed to increase student participation and success in learning. As stated in Law Number 20 Year 2003 concerning the National Education System that education itself has the aim to develop the potential of stu- dents to become human beings who believe in and fear God Almighty, have noble, healthy, knowledgeable, capable, capable, creative, independent, and be a democratic and responsible citizen. Education is an effort to develop student potential (Fonda \& Sumargiyani, 2018), meaning that through education, the potential and talents of students can be developed.

To develop students' potential, students must be active in the learning process. The activity can be achieved by providing an interesting and fun learning media. In line with the opinion (Doriza \& Sunawar, 2016) that by choosing interesting learning resources and fun can increase motivation and interest in learning so that learning objectives will be achieved. The use of instructional media must be in accordance with the level of student needs. With the selection of appropriate learning media, it is expected to improve the learning process and the formation of enjoyable learning so that it triggers an effective learning process. According to (Astalini et al., 2019), excitement in learning is an expression of student emotions that are intrinsically related to student motivation, learning, and school performance at school. Learning media is a strategic thing in the framework of realizing optimal learning processes (Juanda, 2012). The learning process in the 2013 curriculum places Information Technology as a learning tool integrated into all subjects (Sampurno et al., 2015). Increasingly sophisticated technology can be utilized as a learning medium. Technological progress can change people's life patterns (Budiman, 2017). Humans have made use of IT in all their activities (Manongga et al., 2009), almost all human activities are assisted by technology so that humans make technology as an inseparable part.

The development of advances in information technology and communication today has had a major influence on aspects of life, including the world of education (Budiana et al., 2015). The implementation of the 2013 curriculum emphasizes the use of Information Technology for learning media. Learning must be in line with technological developments that have penetrated the world of education. History Information technology itself comes from the world of education. Sophisticated and IT-based learning media is a form of tangible evidence that the world of education is inseparable from the development of IT (Manongga et al., 2009). In Indonesia, the 
use of multimedia as a learning tool is still limited in number. That is caused by the limited application of teaching materials that resemble real examples commonly used by teachers and students in teaching and learning activities. Teaching materials that are often used in the learning process, in general, are print media. In the use of print media such as books, there are some limitations, including the material that is loaded can only be text and images.

If students 'attention is lacking in the learning process then its effectiveness is also like that, in order to attract students' attention, innovation is needed to develop the learning media used by the school in the teachinglearning process optimally. There is a positive impact on learning using teaching materials (Wibowo \& Pratiwi, 2018). Therefore, it is necessary to hold teaching materials that make the learning process enjoyable. One of them is an electronics-based module that is attractively packaged. An electronic module is a form of presentation of independent teaching materials that are presented in electronic format (Sugianto et al., 2013). The advantages of electronic modules can present material with a combination of media such as audio, text, images, and video (Yoan, 2015).

One application that can be used to compile electronic modules is digitizing books. Book digitization software can change the appearance of PDF files to be more interesting as a book. Book digitization is software designed to convert PDF files to flip page forms. According to (Mulyaningsih, N \& Saraswati, D, 2017), Book digitization is a reliable software that is designed to convert PDF files to turning pages of digital publications or digital books. The advantages of this application are (1) being able to provide a flip effect module or a reversible page; (2) making a module with this application is very easy; (3) module display is not only in the form of text and images, but audio and video forms can also be combined in presenting material; (4) the product can be published in the SWF (Shock Wave Flash), HTML (Hypertexts Markup Language) format if it is to be published on the website.

Based on the above problems, this study aims to (1) describe ethno constructivismbased electronic modules using Pro book digitization software; (2) find out the quality and feasibility of electronic modules based on the Pro Book digitalization in the learning pro- cess in class. The research aims at how students' perceptions, interests, and motivations in using electronic modules in the learning process.

\section{Method}

This study was adopted from (Branch, 2009), which uses the ADDIE (Analyze, Design, Develop, Implement, and Evaluate) development model. According to (Branch, 2009), the stages of developing the ADDIE model consist of five steps, namely (1) introduction, (2) planning, (3) development, (4) implementation, and (5) evaluation.

First, the Analysis phase (Analyze) is the first stage before developing a product. At this stage, the needs and objectives of learning are analyzed for what will be learned by students in the form of conformity KI, KD GPA, which refers to the 2013 curriculum. Based on the needs analysis, curriculum and students have not found any teaching material that utilizes technology in learning - relating to the problems and characteristics of students, hardware, and software (Jayanti \& Wiratomo, 2017). Second, the design stage (Design) makes a storyboard consisting of the preparation of the contents of electronic modules such as materials, stories, crafts, and assessment instruments. According to (I. P. Sari, 2018), this activity is a systematic process known as the term design. Third, the Development stage (Development), (I. P. Sari, 2018) this activity contains the realization of product design. After the e-module is designed according to the design, the things needed are looking for learning material that will be presented in the form of pictures, videos, and audio that can attract the attention of the student participants, when the electronic module has been completed, it will be consulted with media experts and material experts to be validated so that researchers can get input. Fourth, the implementation phase (Implementation) The implementation phase is the stage of media testing in schools (Amirullah et al., 2017) after the products developed pass the revision stage and are appropriate to give to students. The electronic module is given to students in grade $\mathrm{V}$ of the Perumnas 112/I Elementary School, which amounts to 21 students to find out the practicality in the electronic module and see students' motivation to use the electronic module. Fifth, the Evaluation stage, which is the final stage of the ADDIE model. This stage is 
the stage of evaluating electronic modules to get suggestions from electronic module users so that they can be revised again. An evaluation phase is carried out to assess the processes and products made (W. Sari, 2017).

The sampling technique in this study is total sampling, which is a way of collecting data by taking elements or members of the population as a whole to be investigated (Nasution, 2017). The sample used was grade V Perumnas 112/I Public Elementary School, Batanghari Regency. The study was conducted in the 2018/2019 school year with 22 students showed in Table 1.

Table 1. Level of Questionnaire Perception and Students' Interest in E-Modules

\begin{tabular}{|c|c|c|c|}
\hline $\begin{array}{c}\text { Interval } \\
\text { Score of } \\
\text { Perception }\end{array}$ & $\begin{array}{l}\text { Interval } \\
\text { Score of } \\
\text { Interest }\end{array}$ & $\begin{array}{c}\text { Interval } \\
\text { Score of } \\
\text { Motivation }\end{array}$ & Criteria \\
\hline $20.0-36.1$ & $20.0-36.1$ & $20.0-36.1$ & Very Bad \\
\hline $36.1-52.0$ & $36.1-52.0$ & $36.1-52.0$ & $\begin{array}{c}\text { Not } \\
\text { Good }\end{array}$ \\
\hline $52.1-68.0$ & $52.1-68.0$ & $52.1-68.0$ & Enough \\
\hline $68.1-84.0$ & $68.1-84.0$ & $68.1-84.0$ & Good \\
\hline $84.1-100.0$ & $\begin{array}{l}84.1- \\
100.0\end{array}$ & $84.1-100.0$ & $\begin{array}{l}\text { Very } \\
\text { Good }\end{array}$ \\
\hline
\end{tabular}

In this study, researchers used a questionnaire to see the interests, motivations, and perceptions of students regarding the ethno constructivism e-module. In the questionnaire used, there are several statements regarding students 'opinions on students' interests, motivations, and perceptions of e-modules. Each questionnaire consisted of 20 statements. The scale used in this study is a Likert scale, which consists of five scales namely $\mathrm{SB}=$ Very good (5), B = Good (4), C = enough (3), $\mathrm{TB}=$ Not Good (2), SB = Very Bad (1).

The product trial phase is a very important part of this development research. The product trial phase is carried out after the product design is complete; it is intended to see whether the product made has the feasibility to be used or not. Data obtained from questionnaires were analyzed using qualitative descriptive statistics. The results of the score are validated, and the average is searched and then converted to determine the validity and feasibility of e-module teaching materials by using the book digitization application. The analysis technique used is the statistical analysis of product trials using SPSS 22 statistical software to see the tendency of the percentage of product user ratings of the appearance and content of the product that has been developed.

Electronic modules using Pro book 4.0 Digitization software, before the module's contents are converted into text with Ms. Office Word and cover pages, are created with Adobe Photoshop software. The e-module file is saved in PDF format and then imported into the book Digitization software.

\section{Results and Discussion}

The results of the development carried out is to produce e-module teaching materials by using the Pro book digitalization application as teaching material supporting the learning process for elementary school students. The electronic modules contain cultural values depicted in the students' cultural norms. The making of modules uses a constructivist approach, so this module is called the ethno constructivism module. Constructivist learning processes support student active participation, knowledge construction, and deep learning, encourage students to think and act independently and foster harvesting learning (Çolak, 2017).

This electronic module contains learning material that is reviewed in terms of culture development of e-modules using the Pro book digitization application. Development products are packaged in PDF (Portable Document Format) format. Ethno constructivism module development is a form of e-learning development so that students are more interested in learning. Electronic modules are made to contain several displays of learning menus, namely learning materials, learning evaluation, craft skills, and assessment of crafts.

\section{A. Homepage (Fig. 1)}

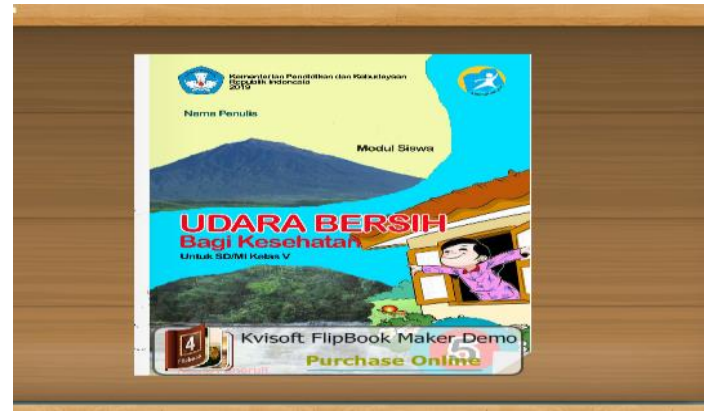

Fig. 1.Homepage

\section{B. Core Competence Page}

This section covers competencies that should be mastered by the students (Fig. 2). 


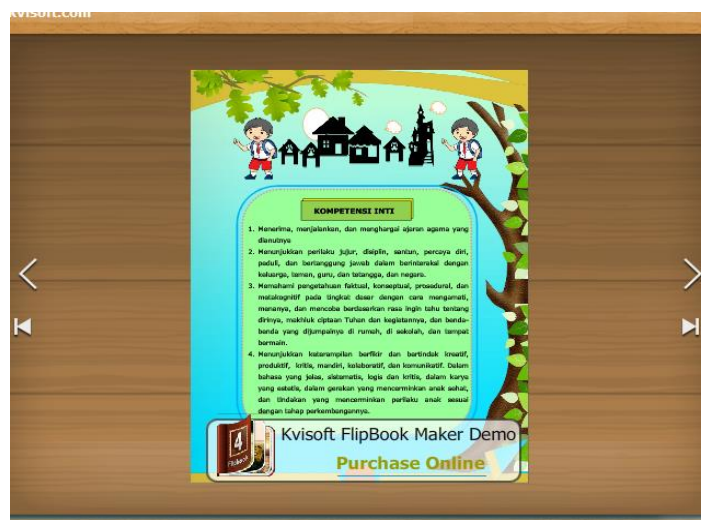

Fig. 2. Core Competence Page

\section{Basic Competence, Indicator, and} Learning Objectives Page

This section includes Basic Competence, Indicator, and Learning Objectives designed for the students (Fig. 3).

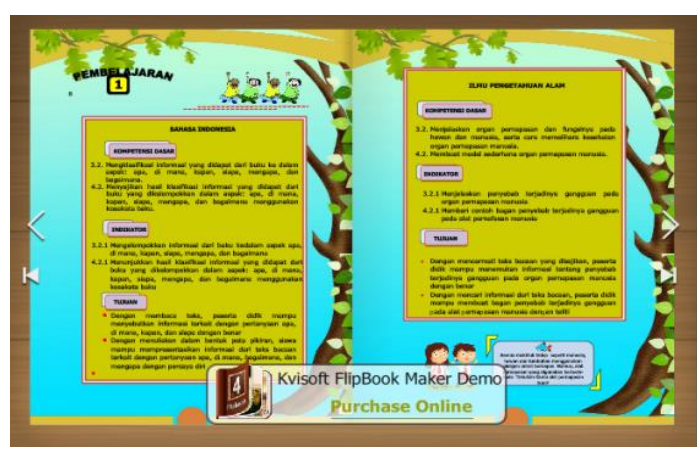

Fig. 3.Basic Competence, Indicator, and Learning Objectives Page

\section{Story Page}

This section covers ethno science, techno social, ethno mathematics, and ethno linguistics depicted in the story. The story is derived from the local wisdom of Jambi Province (Fig. 4).

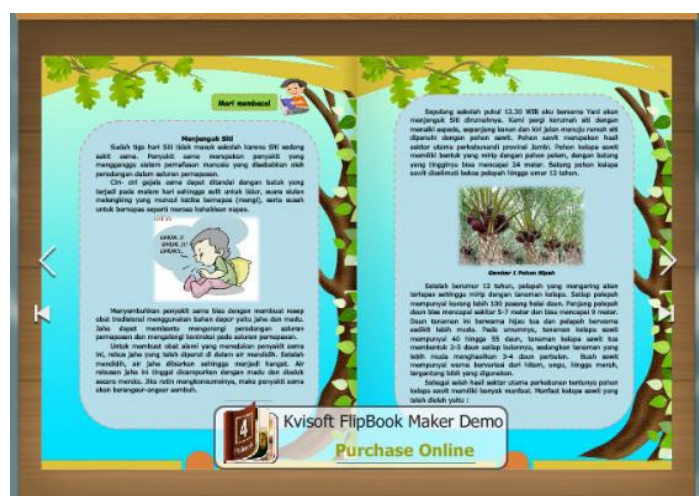

Fig. 4. Story Page

\section{E. Evaluation Page}

This section covers the story evaluation that is comprised of five questions (Fig. 5).

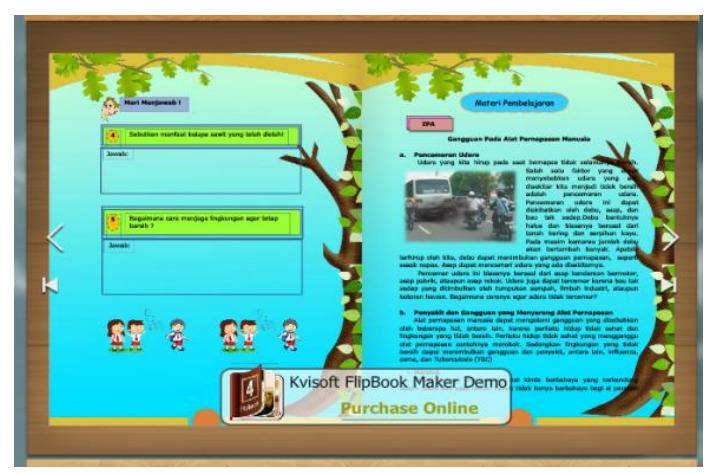

Fig. 5.Evaluation Page

\section{F. Learning Topics Page}

This section covers learning topics that are related to the learning competence (Fig. 6).

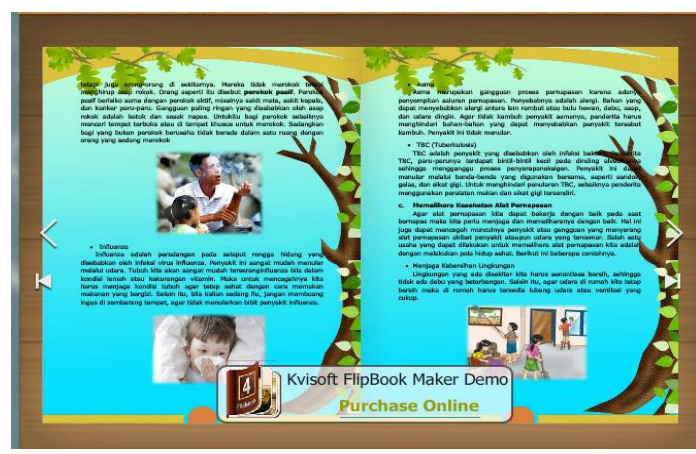

Fig. 6.Learning Topics Page

\section{G. Learning Evaluation Page}

This section covers exercises for the students consisting of five questions (Fig. 7).

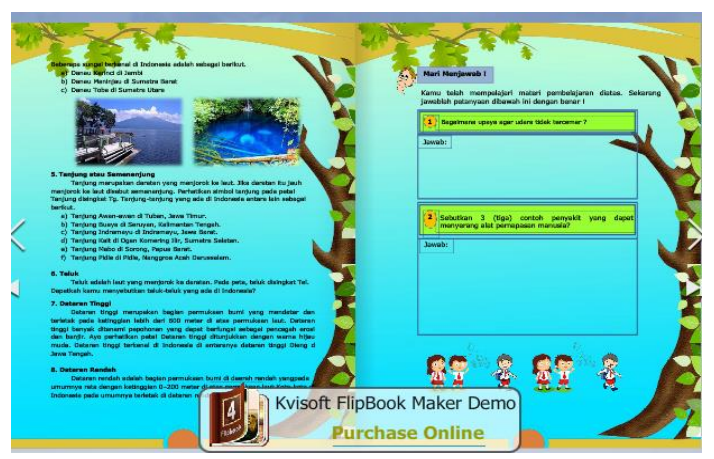

Fig. 7.Learning Evaluation Page

\section{H. Students' Artifact Page}

This section covers space for students' artifact enactment (Fig. 8). 


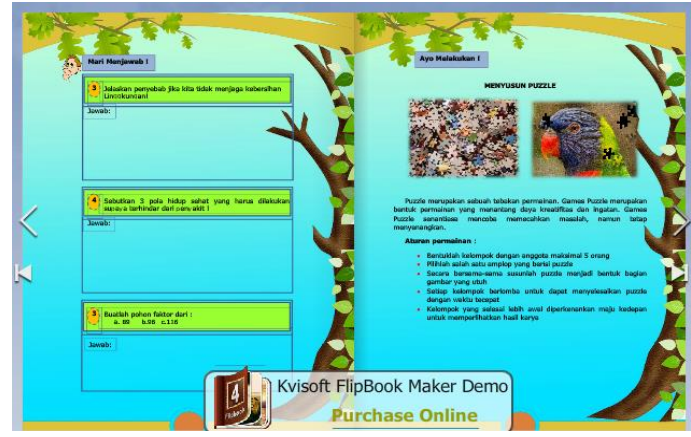

Fig. 8. Artifact page

\section{Artifact Assessment Page}

This section provides space for artifact assessment (Fig. 9).

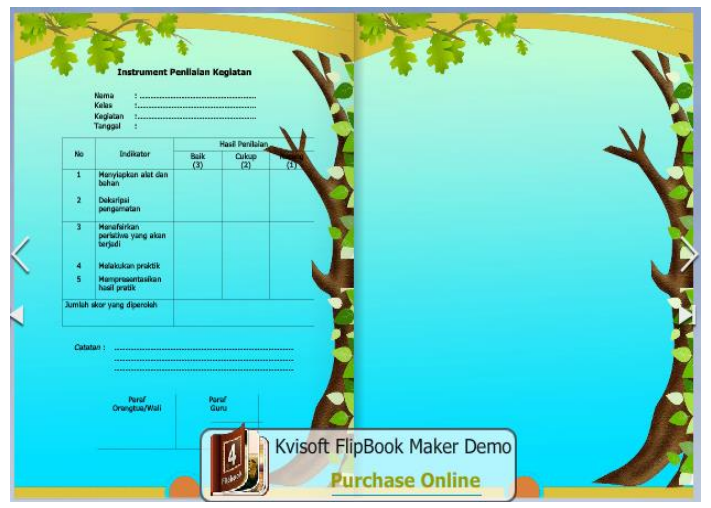

Fig. 9. Artifact Assessment Page

The results of the data from the study using a questionnaire of interests, motivation, and perceptions carried out in grade $\mathrm{V}$ of the Perumnas 112/I Elementary School on emodules using book digitization can be seen in Table 2.

Table 2. Descriptive Statistics of Questionnaire on Interest, Motivation, and Perception

\begin{tabular}{cccccc}
\hline & N & Min & Max & Mean & Stv. Dev \\
\hline Interest & 22 & 68 & 91 & 80.23 & 5.503 \\
Motivation & 22 & 63 & 90 & 76.05 & 6.237 \\
Perception & 22 & 56 & 88 & 68.27 & 9.755 \\
N Valid & 22 & & & & \\
\hline
\end{tabular}

Based on Table 2, the statistical description of the interest questionnaire, the motivation for the e-module, can be seen that the interest data obtained a minimum value of 68 , a maximum value of 91 , a mean of 80.23 , and a Standard Deviation of 5.503. Motivation data obtained a minimum value of 63 , a maximum value of 90 , a mean value of 76.05 , and standard deviation 6.237. While the perception data obtained a minimum value of 56 , a maximum value of 88 , a mean of 68.27 , and Standard Deviation of 9.755. The three ques- tionnaires were given to the same 22 people (N).

Table 3 shows level of the questionnaire categories of interest given to students for the developed e-modules.

Table 3. Level of Categories of Questionnaire on Students' Interest

\begin{tabular}{cccc}
\hline Interval Score & Criteria & F & \% \\
\hline $20.0-36.0$ & Very Bad & 0 & 0 \\
$36.1-52.0$ & Not Good & 0 & 0 \\
$52.1-68.0$ & Enough & 1 & 4.55 \\
$68.1-84.0$ & Good & 16 & 72.73 \\
$81.4-100.0$ & Very Good & 5 & 22.72 \\
& Total & 22 & 100 \\
\hline
\end{tabular}

Based on Table 3, the questionnaire level of student interest in e-modules informs that, at the questionnaire level, the criteria of "Very Bad" and "Not Good" is 0 and a percentage of $0 \%$ ( 0 of 22 students). In terms of "Enough" criteria, it is 1 with a percentage of $4.55 \%$ (1 of 22 students). In the criteria "Good", the percentage is $72.73 \%$ (16 out of 22 students) and "Very Good" is 5 and a percentage of $22.72 \%$ ( 5 of 22 students). Thus, the interest questionnaire was dominated by the "Good" category, with 16 respondents at $72.73 \%$.

Table 4 shows level of motivation questionnaire categories given to students for the e-modules developed.

Table 4. Level of Categories of Questionnaire on Students' Motivation

\begin{tabular}{cccc}
\hline Interval Score & Criteria & F & $\%$ \\
\hline $20.0-36.0$ & Very Bad & 0 & 0 \\
$36.1-52.0$ & Not Good & 0 & 0 \\
$52.1-68.0$ & Enough & 3 & 13.63 \\
$68.1-84.0$ & Good & 17 & 77.27 \\
$84.1-100.0$ & Very Good & 2 & 9.1 \\
& Total & 22 & 100 \\
\hline
\end{tabular}

Based on Table 4, the level of the students' motivation questionnaire category on e-modules informs that, at the questionnaire level, the criteria of Very Bad and Not Good are $0 \%$, meaning that 22 students did not respond to them. The criteria "Enough" is $13.63 \%$ ( 3 out of 22 students), "Good" is 17 with a percentage of $77.27 \%$ (17 of 22 students), and "Very Good" is 2 with a percentage of $9.1 \%$ (2 out of 100). Thus, the dominant motivation questionnaire is in the "Good" category with respondents as many as 17 students amounted to $77.27 \%$. 
Table 5 shows a questionnaire level of perception given to students of the e-module developed.

Table 5. Level of Categories of Questionnaire on Students' Perceptions

\begin{tabular}{cccc}
\hline Interval Score & Criteria & F & $\%$ \\
\hline $20.0-36.0$ & Very Bad & 0 & 0 \\
$36.1-52.0$ & Not Good & 0 & 0 \\
$52.1-68.0$ & Enough & 14 & 63.63 \\
$68.1-84.0$ & Good & 6 & 27.27 \\
$84.1-100.0$ & Very Good & 2 & 9.1 \\
& Total & 22 & 100 \\
\hline
\end{tabular}

Based on table 5, the questionnaire level of students' perceptions of the e-module informs that, at the questionnaire level, the criteria of "Very Bad and Not Good" are 0 and a percentage of $0 \%$ (no voters). The criteria "Enough" are 16 and a percentage of $63.63 \%$ (16 of 22 students). The criteria "Good" is 6 with a percentage of $27.27 \%$ (6 of 22 students), and "Very Good" is 2 and a percentage of 9, $1 \%$ ( 2 of 22 students). It can be concluded that the dominant perception questionnaire is in "Enough" category, with 14 respondents was $63.63 \%$.

This study attempts to determine the interests, motivations, and perceptions of Grade V students at Public Elementary School on the use of e-modules based on digitized books in learning from the questionnaire of interests, motivations, and perceptions. Table 3 portrays those 22 respondents who filled out the interest questionnaire showed the highest frequency of 16 with a percentage of $72.73 \%$ included in the good category. This frequency shows more than half of respondents give or show a positive interest in the use of emodule learning based on digitizing books in learning. That is, if students show a positive interest response, it will increase students' interest in learning more by using e-module learning based on book digitization. According to (Ariawan et al., 2017), The low interest in student learning can be overcome by including entertainment elements in the developed multimedia. According to (Cholid, A et al., 2016; Nurhasanah \& Sobandi, 2016), an interest in learning means that if someone is interested in a lesson, he will have a feeling of interest in the lesson.

Furthermore, from the results of the data in Table 5, of the 22 respondents who filled out the motivation questionnaire showed that the largest frequency of 17 with a percentage of $77.27 \%$ included in the good category.
This frequency shows that more than half of the responses responded that the use of elearning modules based on the Digitalization of books tested was able to motivate students in learning activities. This means that with the e-module learning materials based on digitizing books, students become more motivated in following the learning process. Motivation consists of two types, namely intrinsic motivation and extrinsic motivation (Kurniawan et al., 2019). Based on the statement, there is intrinsic motivation that comes from within the students themselves, and extrinsic motivation comes from outside the students themselves. This means directing the deed to achieve the desired goal. 3) Motivation functions as a driver; it functions as an engine for cars; the size of motivation will determine the speed or slowness of a job (Astalini et al., 2019). According to (Anjani, K et al., 2016), Motivation is essential in determining how much students will learn from a learning activity or how much absorb the information presented to them. According to (Manasia, 2015), Enjoyment in learning is the emotional expression of students intrinsically linked to student motivation to learn, with learning and school performance at school.

From the results of the data obtained in Table 5, from the 22 number of respondents who filled out the perception questionnaire that was distributed show-ed the highest frequency of 14 with a percentage of $63.63 \%$ included in the Fair category. The results of this data indicate students' perceptions of the e-modules tested have received a positive response. This means that the use of teaching materials can provide stimulus to students in learning. According to (Agustami, R et al., 2017), the learning process applied by the teacher initiates the formation of students' perceptions. (Monawati \& Elly, 2017; Putro et al., 2017) said that basically, every student gets a different stimulus from outside himself, with the stimulus then processed into a perception.

\section{Conclusion}

This research and development produce emodules using the book digitization application. The model used to develop the module is ADDIE, which consists of five steps, namely Analyze, Design, Development, Implementation, and Evaluation. From the distribution of questionnaires that have been carried out in the Perumnas 112/I State Primary School, it 
can be concluded that the results of the analysis obtained from the student interest indicators were obtained in the good category with a percentage of $72.73 \%$. Indicators of student motivation are categorized. Good with a percentage of $77.27 \%$, and subsequently, the results of indicators of students' perception of the category are Sufficient with a percentage obtained of $63.6 \%$.

This e-Module with the ethno constructivism learning approach uses a constructivism approach in the hope of making it easier to understand learning especially for teachers, students, academics in the field of basic education. It is hoped that the development of this e-Module can be combined with a gamification approach so that students can be more motivated and success in learning will be higher for elementary level students.

\section{Acknowledgment}

This study was financially supported by a research grant from Kemenristekdikti with the contract number: 0606 / SP2H / RT / DRPM / 2019. The authors also wish to thank all parties involved in this project

\section{References}

Agustami, R, P., Wiyanto, W., \& Alimah, S. (2017). Persepsi guru dan siswa terhadap pembelajaran ipa terpadu serta implikasinya di smp. Journal of Innovative Science Education, 6(1), 96-103.

Amirullah, G., Hardinata, R., \& Biologi, S. P. (2017). Pengembangan mobile learning bagi pembelajaran. Jurnal Kesejahteraan Keluarga Dan Pendidikan, 4(2), 97-101.

Anjani, K, D., Fatchan, A., \& Amirudin, A. (2016). Pengaruh pembelajaran berbasis turnamen dan games terhadap motivasi belajar siswa. Jurnal Pendidikan: Teori, Penelitian, Dan Pengembangan, 1(9), 1787-1790.

Ariawan, B., Muhsetyo, G., \& Qohar, A. (2017). Pengembangan Edutainment Multimedia Belajar Program Linier Siswa Smk. Jurnal Pendidikan: Teori, Penelitian, Dan Pengembangan, 2(6), 780-789.

Asrial, A., Syahrial, S., Kurniawan, D. A., Subandiyo, M., \& Amalina, N. (2019). Exploring obstacles in language learning among prospective primary school teacher. International Journal of Evaluation and Research in Education, 8(2), 249-254. https://doi.org/DOI:10.11591/ijere.v8i2.16 700

Astalini, A., Kurniawan, D. A., Sulistiyo, U., Perdana, R., \& Susbiyanto, S. (2019). Eassessment motivation in physics subjects for senior high school. International
Journal of Software Engineering \& Applicationsof Online and Biomedical Engineering (IJOE), 15(11), 4-15.

Astalini, A., Kurniawan, D. A., \& Sumaryanti, S. (2018). Sikap siswa terhadap pelajaran fisika di sman kabupaten Batanghari. JIPF (Jurnal Ilmu Pendidikan Fisika), 3(2), 5964.

Branch, R. M. (2009). Instructional design: The ADDIE approach (Vol. 722). Springer Science \& Business Media.

Budiana, H. R., Sjafirah, N. A., \& Bakti, I. (2015). Pemanfaatan teknologi informasi dan komunikasi dalam pembelajaran bagi para guru Smpn 2 Kawali desa citeureup kabupaten ciamis. Dharmakarya, 4(1), 5962.

Budiman, H. (2017). Peran teknologi informasi dan komunikasi dalam pendidikan. AlTadzkiyyah: Jurnal Pendidikan Islam, 8(1), 31-43.

Bušljeta, R. (2013). Effective use of teaching and learning resources. Czech-Polish Historical and Pedagogical Journal, 5(2), 55. https://doi.org/https://doi.org/10.2478/cphpj-2013-0014

Cholid, A, A., Elmunsyah, H., \& Patmanthara, S. (2016). Pengembangan model web based learning pada mata pelajaran jaringan dasar paket keahlian TKJ pada SMKN sekota malang. Jurnal Pendidikan: Teori, Penelitian, Dan Pengembangan, 1(5), 961-970.

Çolak, E. (2017). Teachers' Experiences in a Professional Learning Community on The Constructivist Lesson Planning: A Case Study Among Primary School Teachers. Education \& Science/Egitim ve Bilim, 42(190). https://doi.org/https://doi.org/10.15390/EB .2017 .6911

Darmaji, D., Astalini, W, K., Khairul, A., \& Artha, L. (2019). Students' perceptions of electronic's module in physics practicum. Journal of Education and Learning (EduLearn), 13(2), 288-294.

Darmaji, D., Kurniawan, Dw, A., Suryani, A., \& Lestari, A. (2018). An identification of physics pre-service teachers' science process skills through science process skills-based practicum guidebook. Jurnal Ilmiah Pendidikan Fisika Al-Bruni, 7(2), 239-245.

Doriza, S., \& Sunawar, A. (2016). Pengembangan sumber belajar ekonomi keluarga berbasis cd interaktif. Jurnal Ilmu Pendidikan, 2l(1).

Fonda, A., \& Sumargiyani, S. (2018). The developing math electronic module with scientific approach using kvisoft flipbook maker pro for xi grade of senior high school students. Infinity Journal, 7(2), 109-122. 
https://doi.org/https://doi.org/10.22460/infi nity.v7i2.p109-122

Fu, J. (2013). Complexity of ICT in education: A critical literature review and its implications. International Journal of Education and Development Using Ict, 9(1), 112-125.

Ibrahim, M. H. A. R. (2016). Classroom management: the effectiveness of teacher's roles. Education and Linguistics Research, 2(1), 69-84.

Jayanti, M., \& Wiratomo, Y. (2017). Perancangan Media Siap UN Matematika SMP Berbasis Android. SAP (Susunan Artikel Pendidikan), 2(1).

Juanda, E. A. (2012). Media pembelajaran berbasis multimedia interaktif untuk meningkatkan pemahaman dasar-dasar mikrokontroler. Jurnal Ilmu Pendidikan, 17(6).

Kaewkiriya, T. (2013). A design and development of e-learning content for multimedia technology using multimedia game. International Journal of Software Engineering \& Applications, 4(6), 61.

Kurniawan, D. A., Chan, F., Nugroho, P., Pratama, R. A., \& Septiasari, R. (2019). Identification: The effect of mathematical competence on pedagogic competency of prospective teacher. Humanities \& Social Sciences Reviews, 7(4), 85-92.

Manasia, L. (2015). Enjoyment of learning in upper secondary education. An exploratory research. Procedia-Social and Behavioral Sciences, 180, 639-646. https://doi.org/https://doi.org/10.1016/j.sbspro.2015.02.17

Manongga, D., Tambotoh, J., \& Bawu, J. (2009). Perancangan modul pembelajaran berbasis interactive multimedia learning. Jurnal Teknologi Informasi-Aiti, 6(1), 16-29.

Monawati, M., \& Elly, R. (2017). Korelasi persepsi siswa terhadap pembelajaran matematika dengan hasil belajarnya di kelas $\mathrm{v}$ sd negeri i pagar air aceh besarkorelasi persepsi siswa terhadap pembelajaran matematika dengan hasil belajarnya di kelas v SD Negeri i pagar air aceh besar. Jurnal Ilmiah Mahasiswa Pendidikan Guru Sekolah Dasar, 2(1).

Mulyaningsih, N, N., \& Saraswati, D, L. (2017). Penerapan media pembelajaran digital book dengan kvisoft flipbook maker. Jurnal Pendidikan Fisika, 5(1), 25-32.

Nafiati, D. A. (2017). Motivation, creativity, and self-confidence as forming factors of economic learning autonomy. Dinamika Pendidikan, 12(2), 182-195. https://doi.org/https://doi.org/10.15294/dp.v12i2.13566
Nasution, L. M. (2017). Statistik deskriptif. Hikmah, 14(1), 7 .

Nurhasanah, S., \& Sobandi, A. (2016). Minat belajar sebagai determinan hasil belajar siswa. Jurnal Pendidikan Manajemen Perkantoran (JPManper), 1(1), 128-135.

Parjanadze, N. (2009). Globalisation theories and their effect on education. IBSU Scientific Journal, 3(2), 77-88.

Putro, S. C., Elmunsyah, H., Putranto, H., \& Nidhom, A. M. (2017). Pengaruh Aspek Sosial Psikologis Terhadap Kesiapan Menjadi Guru Smk Di Jurusan TE FT UM. Teknologi Dan Kejuruan: Jurnal Teknologi, Kejuruan, Dan Pengajarannya, 40(1), 59-68.

Ratminingsih, N. M. (2018). Implementasi board games dan pengaruhnya terhadap hasil belajar bahasa Inggris. Jurnal Ilmu Pendidikan, 24(1), 19-28.

Sampurno, P. J., Maulidiyah, R., \& Puspitaningrum, H. Z. (2015). Implementasi kurikulum 2013: Moodle (modular object oriented dynamic learning environment) dalam pembelajaran fisika melalui lembar kerja siswa pada materi optik di Sma (halaman 54 sd 58). Jurnal Fisika Indonesia, 19(56), 54-58.

Sari, I. P. (2018). Implementasi model addie dan kompetensi kewirausahaan dosen terhadap motivasi wirausaha mahasiswa. Jurnal Ekonomi Pendidikan Dan Kewirausahaan, 6(1), 83-94.

Sari, W. (2017). Pengembangan modul elektronik berbasis $3 \mathrm{~d}$ pageflip professional pada materi konsep dasar fisika inti dan struktur inti mata kuliah fisika atom dan inti. EduFisika.

Sugianto, D., Abdullah, A. G., Elvyanti, S., \& Muladi, Y. (2013). Modul virtual: Multimedia flipbook dasar teknik digital. Innovation of Vocational Technology Education, 9(2).

Susanti, F. (2015). Pengembangan e-modul dengan aplikasi kvisoft flipbook maker pada pokok bahasan fluida statis untuk peserta didik Sma/Ma kelas $x$. UIN.

Wibowo, E., \& Pratiwi, D. D. (2018). Pengembangan bahan ajar menggunakan aplikasi kvisoft flipbook maker materi himpunan. Desimal: Jurnal Matematika, 1(2), 147-156.

Yoan, A. (2015). Pengembangan Bahan Ajar Interaktif Sebagai Pendukung Implementasi Pembelajaran Berbasis Scientific Approach Pada Materi Jurnal Penyesuaian Siklus Akuntansi Perusahaan Jasa Di Smk Negeri 1 Jombang. Jurnal Pendidikan Akuntansi (JPAK), 3(2), 1-4. 